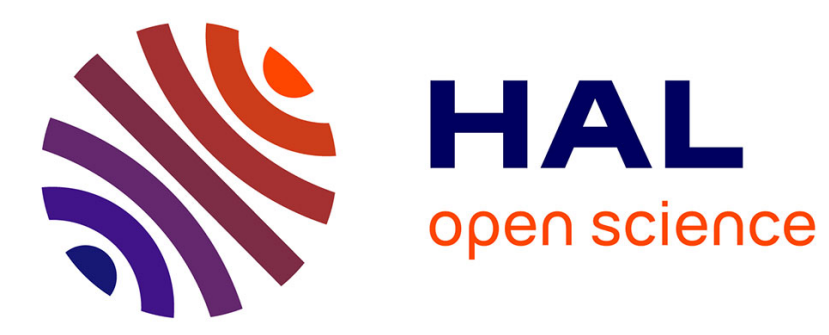

\title{
Scientific misconduct as social misconduct
}

\author{
Juliette Rouchier
}

\section{To cite this version:}

Juliette Rouchier. Scientific misconduct as social misconduct. International Journal of Sustainable Development, 2021, 24 (2), pp.141-154. 10.1504/IJSD.2021.118845 . halshs-03513775

\section{HAL Id: halshs-03513775 https://shs.hal.science/halshs-03513775}

Submitted on 18 Jan 2022

HAL is a multi-disciplinary open access archive for the deposit and dissemination of scientific research documents, whether they are published or not. The documents may come from teaching and research institutions in France or abroad, or from public or private research centers.
L'archive ouverte pluridisciplinaire HAL, est destinée au dépôt et à la diffusion de documents scientifiques de niveau recherche, publiés ou non, émanant des établissements d'enseignement et de recherche français ou étrangers, des laboratoires publics ou privés. 


\title{
Scientific misconduct as social misconduct
}

\section{Juliette Rouchier}

\begin{abstract}
This paper describes processes of disqualification in an environmental dispute, and the impact they [can] have. Scientists, benefiting from an aura of neutrality and reason, publicly express their negative personal opinions as relevant constructed knowledge. This has an impact on the public's level of trust in the scientific inquiry, and can destroy the possibility of doing field work. This is especially the case when the problem under study (here, pollution issues) has strong links with scientific activity, and can generate serious delays in a political process. The disqualification of others being often observed in academics, an institution should be designed to solve such issues with civility.
\end{abstract}

Key-words: environment; long-term policy; policy analytics; French academics; avoidance; disqualification; red muds; instrumentalization of science

Juliette Rouchier, Senior researcher (tenured), LAMSADE, CNRS (PSL) Université Paris-Dauphine

Université Paris-Dauphine, Place Lattre de Tassigny, 75775 Paris Cedex 16

juliette.rouchier@lamsade.dauphine.fr

Juliette Rouchier is originally a mathematician who turned to economics after a PhD in environmental science. For 15 years she worked on self-organizing dynamics for cognitive agents in complex economics, using a modelling tool called agent-based simulation. She worked initially on trust in markets, the diffusion of beliefs and opinions in groups, and later on co-construction of quality of goods, which led her to the question of building democratic spaces of negotiation. Her work then evolved to integrate field studies based on her complexity-cognitive framework of analysis. She now applies her interdisciplinary approach to research on public decision-aiding, and the circumstances in which scientific arguments do not succeed in penetrating public discussion spaces. In parallel she builds theoretical models about the social dynamics that attribute legitimacy to arguments in different spaces.

In this paper, we develop an example based on a failed action-research project, where the misconduct of scientists, in the form of disqualification of the project leader, can be partly incriminated for the failure. Interestingly, this type of misconduct is well-known in science, can arise in many contexts within the academy, and relies on classic social ostracization mechanisms. When it takes place in action-research, the impact is however more important as it can also be deleterious for the concerned field of application, most often environmental, democratic or public health issues. We thus propose a descriptive view on social processes and social impacts that can be induced by power positions, typical of French institutions.

The method of the paper reflects an auto-ethnography focused on the organization that was conducted when the original project of participatory research had to be abandoned. It implied a reorganization and requalification of the relations of the project leader with her colleagues.

1. Introduction

\subsection{Personal judgements in academy}

The question of misconduct in science is not a recent one, as Max Weber already signalled dysfunctions in the academic world in his 1917 conference "Wissenschaft als Beruf" (Science as a Vocation). In his analysis, Weber mainly points at reasons that are of an organizational nature. Structural explanations are also put forward 
regularly, as Petousi and Sifaki (2020) show in this issue, when analysing researchers' discourse. This criticism corresponds to changes in the modes of regulation of research that are partly linked to the extension of its activity, and that have global impacts on the results produced (Fanelli, 2010). The highly competitive climate that has emerged in recent years in the academia is seen by scientists themselves as responsible of amplifying the misconducts in the production of knowledge (Haven et al. 2020)/

As reputation is at the heart of careers and an essential resource, the production of judgement about colleagues can look like a normal phenomenon. This resource is, at the same time, a subject to many reinforcement processes (Rouchier et al., 2001). In particular, the lack of reputation of the person emitting an idea, or the lack of prestige of its institution, can make this idea a priori less important (Morgan et al. 2018). This means that it will not circulate, and the person or institution cannot improve their reputation in return.

The reduction of reputation of the other is also a strategy in the competitive world of academics. Positive or negative judgements circulate widely in the academia, and it can also be observed that extremely uncivil behaviours are common, at least in French universities (Lazar, 2001 ; Dupont, 2014). Being a woman implies a higher risk of being considered of lesser value - as we all know they get less recognition by peers - something that can be assessed in the literature on gender biases discussing career paths (Steinpreis et al ., 1999). On technical issues such an industrial risk, the stereotypical view that women cannot be competent is still present (Zonabend, 2014), and exists within the academic world as much as outside. This point implies that females' reputation are very fragile within the academic world, and their discourse is easily disqualified or not listened to, which is true for different categories of population (Go, 2017).

\subsection{Delaying the proof: a strategy}

Nuisance and pollution issues have been a burden since the beginning of the Industrial Revolution, and have ever since opposed people with heterogeneous power and access to the resources of political discussion. In general, the inhabitants' experience and worries have been considered as irrelevant, and the interest of industrial shareholders has mainly been put forward (Leroux, 2016). Even excessively salient situations, like a very obvious poisoning of population by mercury in Minamata, Japan (Tsuda et al., 2009), have rarely been treated in their relevant time. Populations facing large costs have to be able to organize a strong political contestation if they are to be heard when defending their quality of life or their health. The pro-industrial stance that can be found still today in most developed countries has for example led to the emergence of the field of environmental justice (Allen, 2003 ; Deldreve and Candau, 2014). The research interest of this trend is to demonstrate how inhabitants' experiences of cohabitation with industries are often rejected because of the lack of proof of the impact of a nuisance. "Proof" in this context has to be made, as usual in the modern world, as following the natural sciences' type of demonstration: using clear measures and quantitative evidences either of the presence of certain dangerous materials (eco-toxicology) or of the fact that a population is effectively impacted by its presence at a given place (epidemiology). The requirement of this type of demonstration is often associated with a disqualification of the worries of populations, whose knowledge and experience are not recognized. It is all the easier to disqualify the part of the public that has not achieved higher education, as they easily consider themselves as suffering from epistemic inequality, which makes them feel (to a large extent) unable to argue properly.

This is a situation that is also observed within the field of agnotology - the study of the delay in the production of knowledge about certain dangerous substances (Proctor and Schiebinger, 2008). In his work, Proctor (2012) demonstrated how the industrial world has organized this non-demonstration in the case of tobacco, but the demonstration has since been extended to other goods. He shows how strong evidences were considered as non-acceptable by public authorities to establish laws that could have protected consumers: for decades, communication campaigns, lobbying and corruption networks were used in different ways to differ decisions. The goods at stake were of course representing high incomes for large (and thus powerful) industrial firms. Interestingly, one of the recurring delaying tactics is the rejection of scientific proofs, using disqualification against individuals who produce the evidence (Proctor, 2012). Instead of attacking the content of demonstration, the argument that is used is the ad hominem attack: by disqualifying the person who carries the disturbing argument or proof, one can convince less informed people that this proof is wrong. Of course, this process is possible to overcome so as to establish the truth, but once distrust had been put on a person, 
the rehabilitation of trust can take time. And gaining time is actually what doubtmongers aim at, since they work in the logic of short-time profit of financial capitalism (Ogien, 2015). This practice - postponing scientific demonstration of danger to make an industrial rent last - has become rather popular, which helps explaining why the trust of civil society in science has fallen in time.

Getting back to the issue of reputation, the use of stereotypes for purposes of disqualification can be identified in many contexts (Elias and Scotson, 1965), and be more or less voluntary. When in need to negatively qualify a community, a solution is to refer to the worst behaviours of the most deviant members of the group, and extrapolate it as a tendency of the whole group - even if they are not representative at all. But this reduction can take place because some informations are deceitful: it has been proven that since some scientists accept to dissimulate, falsify, or abusively interpret results in exchange for money or career gains, all scientists lose their image of pure producers of knowledge. The supreme value that was put in the neutrality of science in many (simplistic) discourses is fast eroding, and any scientist today can be seen as being ready to falsify data for personal interest.

\subsection{Case-study: a failed action-research}

The case described here is the failure of an action-research project that tried to organize participatory modelling among opposing actors in the "Red mud" case near Marseille. The context is a long lasting conflict that has arisen and disappeared regularly over the last 40 years, and has involved "science" (as expertise for surveillance and council) at climax points. Red mud is the residue of the Bayer process for alumina extraction from bauxite. After alumina has been diluted in soda, the remaining product is mostly bauxite without alumina, which means that the elements are more concentrated than they were before. This is not a problem with regards to iron (which gives the color to bauxite and red mud), but is a bit more delicate (for sanitary reasons) when it comes to arsenic or vanadium, also natural constituents of bauxite, or to alumina traces remaining after extraction. The plant under study (possessed by Alteo) was initially built at the outskirt of Gardanne, but is today within the limits of this city of about 20,000 inhabitants. Since the beginning, residues have been produced from the extraction of alumina, and have been stocked in diverse places in the county (four large disposal sites are documented today). Let's notice that the management of red mud is an international problem, since every production plant gets rid of about half the volume of bauxite that is used in the process (Mioche, 2011). Usually, the residue is stocked, which is not considered as a problem (socially or regulatorywise) when the density of urbanization is low. In Gardanne, this condition does not hold, and the disposal of residues started to become a problem in the 1960s, which led to conceiving a solution (Loison, Pezet, 2006; Mioche, 2011): a $50 \mathrm{~km}$ pipeline was built, from Gardanne to the sea, to send the overwhelming waste into a deep sea canyon.

From the very beginning of the story, this controversial situation has been linked to scientists' attitudes and points of view in a very intimate way. The paper by Loison and Pezet (2006) shows how the 1965 decision to release the toxic mud in the sea was preceded by an attempt by the industry to try to prove the harmlessness of the product. It has to be noted that, although the recent controversy has raised heavy criticism on Pechiney (owner of the plant at that time), this initiative was extremely uncommon at that time, and in a sense it was perceived as progressive. The industry did order some studies on the content of the residue, which was deemed "reasonably" toxic. It also asked an internationally renowned oceanographer, Jacques Cousteau, to attest that the ocean would not suffer with the discharge. The main argument given was that the sea is very large and the residue was to be sent to the bottom of an abyss that was almost impossible to explore at that time. On the opposite side, a biologist and doctor, Alain Bompard was opposed from the very beginning to the principle of throwing toxic material into the sea, announcing that this would create a precedent for the industry, and that it would soon be mundane to pollute. The scientific justification, and the open discussions that were held with the public, actually had the opposite effect from what was expected by the industry: it built a very strong opposition, in which the mayor of the cities that lived on costal tourism were very active. Eventually, at some point the industry had to stop the transparency process and turned to their main supporter, the Ministry of the Industry, who gave the authorization without any further discussion, as Pechiney was still a prominent national company. At that point, "science" had already turned into a central actor, but it had not played the smooth role that was expected from it.

In 1995, the Ministry of the Environment noted that the pollution was against the newly ratified Barcelona Convention, and gave 20 years to the factory to stop it. In 2012, a new National Park was created in the 
Marseilles area, after rather difficult negotiations (Deldrève et Deboudt, 2012): the Park indeed was intended to include two major polluters, and to exist in a very densely populated area, which is a rare experimental device only found in Pretoria and in Sydney. When the decision was made, the minister of the environment at the time promised that the red muds would no longer be dumped to the sea in this area. Starting in 2014, new negotiations were launched between the State and the industry, experts were hired to assess the risks, and commissions were formed at local and national level, which included non-profits, industry and administrative representatives. The technique that was accepted as the "best available" after a long negotiation between the State and the firm, mixing technical expertise, political and economical arguments, was to press the red muds to get rid of the liquid, eliminate the liquid in the sea and stock the residues near the plant. After the commissions had given their points of view, the prefect allowed for a six-year exemption, starting from January, $1^{\text {st }}, 2016$. The plant could not discharge mud anymore, but was allowed to run its activity and to release filtered water with pollution levels above the limits of the Barcelona convention (especially for Arsenic and Aluminum). The scientific council of the National Park had indeed approved the project, subject to an independent control and monitoring of the pipeline, and a request to be soon respecting the thresholds of the Barcelona convention. From this point onwards, a political dispute exploded to contest the decision, and to force a discussion about the future of this industry and its risks. This dispute was very vivid for most of year 2016 -the period we focus on in this paper - and still lasts, worrying and spreading distrust in the population. The approval by scientists was a major point of contestation by the opponents of the decision.

At the beginning of 2016, the action-research work started, thanks to a funded project that included local social science researchers who had already made field studies in the area for months. The aim was to produce a roleplaying game, following the ComMod methodology (Etienne, 2014), to help reduce the oppositions and potentially re-establish a dialog between several parties. Data were supposed to come from the preceding field studies. The idea was that two pollutions instead of one were now visible: one on earth and one in the sea. Reducing the pollution in the sea would create more problems for the people living around the plant and the stocking place. But the sea had been polluted for a long time, and economic and recreational activities linked to the sea were massively impacted there. How could "ecological solidarity" be envisioned? This type of actionresearch is not meant to propose a solution to a problem identified by an expert, but to co-construct as much as possible the definition of an issue and explore the multiplicity of solutions that can be offered by those who feel concerned about it. In that sense it is a posture of decision-aiding, providing an aid to formalize the issue and a support for mediated encounters to create collective intelligence.

After a few weeks, it was however clear that there had been a major misunderstanding in the project, and that no social science inquiry had been done to establish the actual knowledge and representation of the population at stake, and certainly not in a way that could enable to create a complex model. To be able to start out a minimal model for a game, it was necessary to get data about the views of the system from different individuals involved (with a focus on what they see as the actors, their stakes, interactions, physical impacts, flows, and possible solutions). The project started to change as it was necessary to conduct prior interviews with stakeholders, to draw cognitive maps of the system and lists of arguments. A list of people willing to be part of the game was also drawn. At this point, the project team exploded and the head of the project started to be accused of collusion with the activists and of lack of objectivity. We describe here the situation, as experienced through the participant observation that consisted in "leading a field study" in the usual manner, including interviews and observations. The conflict situation meant that the neutrality of the researcher had to be even more important than in a situation where the observer is not as visible, and since even the "attackers" (the gossiping individuals) had to be given the right to express their point of view in the study. The ethical aspect is as hard to follow as it is central in this type of configuration, which partly relies on auto-ethnography (Armstrong-Gibbs, 2019).

\section{A fabric of distrust}

\subsection{Refusal of communication}

From the very beginning of the interviews, it got clear that distrust was important in the conflict. Most of interviewees were unwilling to meet each other, and expressed very negative views on the others, not only those being on the opposite side of the "pro-anti" line. In time, some people even refused to be interviewed. 
The mistrust was expressed by everyone, although the activists would systematically express willingness to meet others to confront points of view. However they would recognize a huge power gap between them and other stakeholders, and also consider that other parties (such as "the factory") were of bad faith - in the sense they had no hope that a meeting could occur, let alone a constructive dialog take place. Others' intentions (from the three other categories) were always seen as manipulative, and in particular the lack of recognition about their own knowledge and worries was considered as despiteful. This is a common element of environmental justice analysis, whereby inhabitants feel they face too large epistemic asymmetries and too little space for dialog (Vermeylen, 2019).

In 2016, the activists also started to argue against each other. They teamed up to lead a large demonstration of some 2,000 people in January 2016. However, during this demonstration, several strategies were visible: those who wanted to increase the visibility at national level created links with national activists (in particular José Bové, very important amongst French environmentalists), while others were trying to work at a local scale by joining more local associations. From this point onwards, accusations of safeguarding his own interest were made against one of the main activists, judged too radical and unable to negotiate. He would retort that others were ready for any compromise with the authorities. As a result, in September 2016, two demonstrations were run in different places and at different times, following different calls. An email recommendation among one of the networks circulated not to join the other demonstration - leading its participation to fall to approximately 200. Other activists were excluded from all networks but carried on working on their own - one of them writing a blog on the topic on a national journal site, for example. Even among networked activists, it was becoming impossible to have people meet and discuss. This is a rather usual political process, in particular in France (Lamont and Thévenot, 2000). At a moment, the conflict was so worked up that two interviewees recommended (as a joke, but only partially so) to find a bodyguard before carrying on with the inquiry.

\subsection{Stressing epistemic inequalities}

As said before, scientists were seen as central actors, although their image was quite rarely positive. Most of them were considered as "in collusion" with the plant, having unexpressed conflict of interest (when not being directly corrupted) - gossip and rumours were very prevalent about several visible researchers in charge of expertise.

Conversely, some of these scientists were producing public discourses about other actors, and were in that way defining the frame of the acceptable definition of the problem: the most central idea was that all activists wanted to close the factory. The second general idea was that the public was not able to understand the higher stakes of the situation and emitted criticisms that were not well founded. Any activist could be thus disqualified on grounds of their intentions and abilities except, for the latter, those coming from the academic world (retired professors). It was also said that activists necessarily try to "instrumentalize" researchers and that one has to be very careful when approaching them. Soon after starting with the interviews, it became clear that the idea of closing the factory was supported only by one rather marginal activist (in a sample of eight). The proposals the interviewees were making were in general much richer, and displaying a good knowledge of the industrial complementarity of the area, with analyses that were often very close to the scientists' ones (Meinard, Rouchier, 2019). Higher-level considerations were present (justice, law, equity, progress), as well as detailed knowledge about the past. It can be noted that the deception in the political process and the lack of response by the administration changed the point of view of activists over time, who were more numerous to ask for the closure of the factory in 2017. One other researcher, a sociologist, was leading field interviews at that time, but she had not yet produced any public discourse and was not located in Marseille - thus not in the local network dealing with environmental issues. Until 2015, and although the National Park had existed for some time and the conflict had already started, no one had done a review of firsthand arguments or proposals of the activists. This did not prevent the spreading by central actors of the consensual definition of their points of view.

It was then possible to trace back where the idea of "closing the factory" came from among the researchers, either formally in interviews or informally in meetings. The question "why do you believe that activists want to close the factory?" received two types of answer: "because X said it in a meeting at occasion O" (precise description for getting information) or "because I know someone who knows an activist, and he says that they are manipulative" (imprecise, relying on interpretation rather than description). The structure of justification is clearly of different form, and could serve as a discriminatory identification of primary and secondary sources in 
the building of stereotypes and gossip, following the analysis made by Elias (Elias and Scoson, 1965). It then happens that the producers of disqualification are those who refused interviews later in the year. This type of rationalization could not be recorded precisely, nor the reason to produce them. However, the identified "group" had some people in common with those who circulated other types of judgements, described in the next section. One explanation for this very simplistic view of activists was the fact that, at this time, a thesis was disseminated on media coverage of the conflict - which were oversimplistic and polarized views of the situation - and this study could potentially produce a mix between speech and reported speech.

\subsection{Extending distrust within science networks}

Scientists were also constructing sharp discourses against each other. It was striking to see that any detail would create distrust because the person at stake could be deemed "partial". A one-off commentary was considered as wrong; accusations of not revealing conflicts of interest were made; eventually some researchers were considered as being partial. This last criticism was particularly directed toward the cited project leader, along with questions about her skills, which permitted to observe how such disqualification could have an impact on the possibility to lead the research. Interestingly, the world of interdisciplinary research for environment studies is rather small in the area, so the disqualification was regularly heard by people (researchers and administrative bodies) who could report it almost in real time. At least three people were regularly expressing the fact that they did not trust the project leader who was "on the side of activists" or "against the plant". This lack of neutrality was also explained to a non-academic, an important administrator of the Park.

After this beginning of constant reciprocal expression of doubt, three researchers for the scientific council of the park refused to be interviewed. The first one to "keep its neutrality as an involved expert"; the two others had first agreed and then stopped answering emails. It was then impossible to get an interview with an important administrator of the Park. To get an idea of how unusual the situation: the factory director and a former minister accepted to be interviewed, but not researchers who were initially part of the project. Things got even more complex to lead interviews when a new accusation - "stealing" of a PhD's field study - started to circulate. Eventually the last researchers of the project used the interview grid of the project leader without accepting to share results, despite this being an ex-ante agreement. All this took place between January 2016 and June 2016, eventually bringing the field study to a halt, but also to the public sharing of preliminary results.

The reputation carried on moving in the small world of interdisciplary research: in September of 2016, one colleague, who had never met the project leader expressed worries to another colleague who had involved the project leader in another study. "Have you heard of her reputation?" was the question asked. Interestingly, two years later, the name of the project leader was still associated to a "partial" person: the director of the company, Alteo, reacted to the name, in front of the prefect "if $X$ is involved, then the study will not be accused to be on the side of the industry!".

Thus, the construction and circulation of the reputation is of usual nature, as a pure social dynamics (Elias and Scotson, 1965). The reputation circulates within already existing groups who trust on another, behind the back of the person, who is unable to confront and prove the opposite. Whatever the person does to try to change the situation is useless, as the doubt is already engrained, and since no one listens to the untrustworthy person if the gossiping person has more authority in the social context.

\subsection{Disqualification: why it happened and what were its consequences}

One assumption is that the emergence of this reputation is linked to the structure of the field study. Since the activists' main goal was to be recognized as rational interlocutors, the project leader was immediately welcome, giving weight to the claims by her sheer listening. Even without power in the decision process, the fact of just leading a survey was made easy by the enthusiasm of the first interviewees, who helped deciding whom to meet and gave access to the field. This was a rather uncommon "success" when compared to other field studies, where phone numbers are not easily handed out. This welcoming dynamics did not last, and they faded as the group of activists exploded with reciprocal criticisms. In addition, the whole group of activists was composed of men, while the project leader was a woman: in this context, she was certainly not "threatening", which is an advantage on some fields (Fournier, 2006). But this strong relational dynamics, right from the 
beginning of the field study, was unusual enough to cast doubt on the researcher. It is possible to guess thatseen from outside and without any interest in the details of the research-one could consider the project leader to be "too well integrated" among the activists.

Another assumption is that those disseminating bad reputation were also those who were judged of being on the side of the industrial company by activists and other scientist during the interviews. Two of them had been following the functioning of the plant (either on the evolution of depollution devices, or of the pollution in the sea) for at least a decade without signalling any problem. One had already used disqualification on other female colleagues: this was known by some activists and increased the general distrust scientific participants. In this "group" of scientists, one criticized a colleague of being "irresponsible" because he had identified and expressed in front of the press a conflict of interest concerning the public inquiry. Mindless of whether there was indeed a conflict of interest, and of how much distrust this could cause among the inhabitants, the scientist publicly expressed his criticism. Another one expressed in a conference the idea that there was no longer a problem, since the "muds" were not thrown in the sea: "it is now a historic problem, not contemporary anymore", which was shocking for a part of the audience.

Although these people were part of the Scientific Council of the Park, they never asked for a sociological prestudy in parallel to the chemical analysis. There can be two interpretations for this: either it seemed legitimate to frame the issue on its own, without further sociologic study but for a few discussions; or they might have perceived the current field study as an open contradiction to their knowledge and central position in the problem. This, of course, was discovered during the field study.

Whatever the reasons for this circulation of gossip, it transformed the project leader's mindset on the field. In a positive way, it forced a more serious reflection on the building of local interdisciplinary spaces, which was made easier because the project leader was (Faulkner and Becker, 2006). This lead to an analysis of the networks that created relative legitimacy of people, and how co-optation was working, how beliefs were created, and in particular the role of interdisciplinarity in this. In particular, when only one social scientist is present in an interdisciplinary committee, he/she can declare many things and pretend to objectivity, without ever being contradicted. In a negative way, it made the project leader much more irascible and less resistant to remarks: it reduced neutrality while creating polarization, the simple evocation of some individuals would dismiss the credibility of the transmitted knowledge. To fight this disturbing situation, that reduced the ability to think straight, the project leader had to completely reconfigure her network, and connect with colleagues that were less easy to influence, and had already spotted the self-reinforcing beliefs of the described group.

Another aspect is the loss of time. Since the accusation was of using wrong methods, of not being professional enough for the job, and of being partial, there were long attempts to explain to unhappy observers the work that was being led. The time spent in this attempt at pacification was considerable, and it was a complete waste since no one accepted to meet with the project leader.

It took some time to decide to simply drop the field research for some time, as it was just creating more chaos in a complex situation. Instead of building a game for creating a space of participation, another game was built based on the representations of the main constraints, and on a theoretical common-good situation. It took the form of an education game for children and teenagers. I also postponed the circulation of the information already gathered, which meant that the "knowledge" created got stored away without having any use. Instead, it could have informed what participatory sciences consider an arena of confrontation. A new study was led, and the project leader requested as an expert to help designing it, then three years later to join new discussions with the Prefect. This new study was led by a private counselling company, which appeared as more "neutral" - most ideas found in this study were not new, but for some considerations about inhabitants living far away from the factory that had not been identified previously.

\section{Implication for participatory sciences}

Several aspects can again be underlined following the description of the problem of disqualification made by scientists in this context. 
In a very direct manner, a participatory research is of course ruined as soon as the legitimacy of the researcher starts to be questioned. In this type of work, the researcher needs to propose modalities of interactions, as well as an intermediary object for discussion. Both are the result of the work of the scientist, either his.her choice for interacting, and the choices made for the model. However strict in the co-construction and the organization to produce neutrality in the synthesis of points of view, it is very unlikely that the modelling proposed by a scientist will be seen as "neutral". Thus if the scientist is publicly disqualified, all the research process loses its social support. It has much higher chances not to take place at all. This means delaying the production of knowledge. This can mean, like in the described case, waiting for months for the recognition of activists' rationales, knowledge and ability to make sound proposals.

There is one particularity of field studies that is particularly salient in action-research (and thus participatory science): the situation that is studied is in general quickly evolving, and often pushes to adapt the research. When discussing social relations for example, one can see that roles, influences, and power relations are unstable: new emerging patterns are of interest for a process of collective intelligence (action), as well as for the analysis of human and social laws (research) (Barnaud and van Paasen, 2013). This type of research is typically the one where the initial and final research questions of a project diverge. This implies that one has to be alert and flexible in the perception and analysis of events, which a priori requires a certain state of mind: relaxation, openness and accurate sensitivity to others (Favret-Saada, 2009). Disqualification, this very common French passion (as shown by Laugier and Ogien (2017) on the use of populism), has very strong impacts on the emotions of the person who is disqualified and reduces their ability and freedom of thought. This research posture already suffers when high levels of tension are present among the actors, but it is even more difficult to carry when hostility is turned towards oneself, and that one feels the need to justify one's actions. It is then easy to doubt of one's own abilities, even if only for short periods of time, which can bring to a halt the construction of a project.

The problem in this type of conflicting field work is that it is easier to get opinions than facts, and that each discourse is already heavily orientated towards an interpretation. In our operational perspective (Tsoukias et al., 2013), it is necessary to understand where arguments come from and how they articulate a possible demonstration - be it scientific or from everyday experience. The understanding of the complexity of interviewees' representations implies to be able to communicate with other disciplines and other scientists who can propose other points of view and analyses of the same setting. When being ostracized, it is much harder to achieve good communication conditions with colleagues, with an open attitude that enables to argue positively, since defiance has to be overcome first. One method then is to create trust among an alternative group of colleagues (Williams, 2007) who also work on the same topic - not an easy feat in today's very specialized research world, where few if any colleagues are actually working on the same topic and in the same local community. Thus, the constitution of a sub-network where trust is vivid and enables good discussions is a long-term work. Again, this makes the collection of information and the analysis of the situation much longer to make.

The frontier between engagement and activism is a very strongly discussed topic when it comes to environment and health, but is mainly put forward by those who are engaged in the " normal " political process (following French administrative rules). Such individuals will hardly ever speak out on the way the process should, or at least could, alternatively be led. The lack of protected spaces of discussion within the academic world, where the construction of deep and complex exchanges is guaranteed, is striking in this type of context. Disqualification, such as the one faced by many researchers who oppose the mainstream, could certainly be reduced if universities were willing to produce higher-level knowledge. The Seralini case, a criticized demonstration of potential dangers of GMOs in food (Seralini et al. 2012), could be prototypical: his public disqualification has prevented a reasonable exchange of arguments on the question of methodologies of proof. It could have been an excellent occasion for this, and instead ended up in a polarization of discourses that add little (if anything at all) to a very central political issue.

A word on the meta-level and long run aspects of disqualification. Although the participatory process is necessarily deeply affected, the situation of public disqualification of the scientist can also be seen as a mise en abyme, and thus reflexively reveal the main issues in the public situation that is analysed. As seen in the description of the case, the occurrence of disqualification permitted to identify the process of public speech 
production, and then observe this disqualification tendency circulate within the system. The mechanism behind the survival of the disqualification through time was also clear: the refusal of direct confrontation to expose and argue on the actual work (the content), which would have left those who refused confrontation with their interpretative speech, relying on light evidences. This systematic avoidance, in parallel with regular production of negative discourses, can be interpreted as an efficient strategy to ignore results that might be perceived as disturbing. We get back to the idea that ignoring instead of discussing is an efficient way to preserve status quo, as observed by environmental justice theorists (Allen, 2003). It is a good way to buy some time for industries in the defense of their nuisances. The possibility to discuss in a setting where everyone is protected of asymmetries of power and network support could be one way forward to avoid (in the academic world) the type of ignorance-producing trap in which this community seems to have navigated for some months. Such an institution could also seriously reduce resentment.

It so happens that there is no regulatory body concerning the behaviors of researchers in public spaces, nor the spreading of reputation. There are no incentives to self-regulation. In the contemporary context, power relations associated to the rent-seeking through massive projects can conduct to awkward positions when control of speech is held by people with low ethical standards, against whom no claim can be made. This dynamics are part of the functioning of the fabric of doubt, as studied by Proctor's famous agnotology (Proctor and Schiebinger, 2008). This problem is here documented in a specific case of involvement of French scholars in expertise. But only strong state institutions can impose a dialog that is not desired by certain sub-networks of scientists, whatever their aim is when they refuse an open dispute. One could refer to ethical comities when thinking of this institution, as it could be considered as a deontological ethic of science to accept dialog. It could also be considered as an institution favoring democracy, as any place of public confrontation of opposing views where each speaker is considered as equal, and where only arguments and proofs are judged, can be interpreted in this direction.

\section{Conclusion}

This paper shows how the public expression of personal points of view by scientists can cause problems in the context of a long-lasting environmental conflict. Some people, who were considered as experts, took this opportunity to frame scientifically the issues at stake - without having actually worked on them to be able to justify their point. The methods of communication, including gossip, created a tension that reduced the ability to realize that the framing was illegitimate from a scientific point of view, and that it also had consequences on administrative bodies. Over four years after the situation that is described in the paper, the mix between science and politics is still very vivid, but little usable information or data have been produced to help decisionmaking. The prefect commanded in 2018 a study on the grievance of the inhabitants - the protocol was constructed in April 2018 and stabilized in July 2018. The results will be presented publicly in January 2021. Following Proctor and Schiebinger (2008), buying time in the demonstration of nuisances is a classic industrial strategy: here, four years have been wasted between the initial project aiming at gathering the information about people's representations and the diffusion of this information.

We can then see that this scientific misconduct is social in two ways: it is built through social processes that are already documented (gossiping, ostracization, network reinforcement of power); and takes place within the scientific community but can have serious impacts in the outside world. It thus represents a social misconduct per se.

Allen, B. (2003) Uneasy alchemy: citizens and experts in Louisiana's chemical corridor disputes, MIT Press, Cambridge.

Armstrong-Gibbs, FD (2019) On becoming an organizational autoethnographer; considering the ethical perspectives of the research application process. Journal of Organizational Ethnography, https://doi.org/10.1108/JOE-11-2017-0058.

Barnaud C., van Paassen A. 2013. Equity, power games, and legitimacy: Dilemmas of participatory natural resource management. Ecology and Society 18 (2) 21.

Deldrève, V. and Candau, J. (2014) 'Producing Fair Environmental Inequalities?', Sociologie, Vol. 5, No 3., pp 255-269.

Deldrève, V. Debout, P. (Eds) (2012) Le parc national des Calanques. Construction territoriale, concertation et usages, Quae, Versailles. 
Dupont Y., 2014, L'université en miettes. Servitude volontaire, lutte des places et sorcellerie, éditions l'échappée, Paris.

Elias, N. and Scoson, J. (1965) The Established and the Outsiders: A Sociological Enquiry into Community Problems, Frank Cass, London.

Etienne, E. (2014) Companion Modelling: A Participatory Approach to Support Sustainable Development, Springer, Quae, Versailles.

Fanelli, 2010, Do Pressures to Publish Increase Scientists' Bias? An Empirical Support from US States Data, PlosOne, https://doi.org/10.1371/journal.pone.0010271.

Faulkner, R.R. and Becker H.S. (2008) 'Studying Something You Are Part Of : The View From the Bandstand', Ethnologie française, Vol. 38, No 1, pp. 15-21.

Favret-Saada, J. (2009) Désorceler, Editions de l'Olivier, Paris.

Fournier, P. (2006) 'Le sexe et l'âge de l'ethnographe: éclairants pour l'enquêté, contraignants pour l'enquêteur, ethnographiques.org, n 11, http://www.ethnographiques.org/2006/Fournier.

Funtowicz, S. and Ravetz, J. (1993) Science for the post-normal age, Futures, Sept. 1993, pp $739-755$.

Leroux, T. (2016) , 'Chemistry and Industrial and Environmental Governance in France, 1770-1830', History of Science, Vol. 54, No 2, pp 195-222.

Go J., 2017, Decolonizing Sociology: Epistemic Inequality and Sociological Thought, Social Problems, Volume 64, Issue 2, May 2017, Pages 194-199, https://doi.org/10.1093/socpro/spx002

Haven T. Pasman H.R., Widdershoven G., Tijdink J.K., 2020, Researchers' Perceptions of a Responsible Research Climate: A Multi Focus Group Study, 10.1007/s11948-020-00256-8

Lamont, M. and Thévenot, L. (Eds) (2000) Rethinking Comparative Cultural Sociology: Repertoires of Evaluation in France and the United States, Cambridge University Press, Cambridge.

Meinard Y., Rouchier J., 2019, L' " argument économique » dans l'aide à la décision en politique

environnementale et son évanescence : réflexions à partir du cas des « boues rouges » de Gardanne, Nature Science Société, 27, 4, 399-409, https://doi.org/10.1051/nss/2020006.

Mioche, P., 2011. Alumine et risques industriels : le cas des boues rouges et des résidus. Aix-en-Provence, CNRS-OHM Bassin Minier de Provence, Document de travail OHM, 1, 25 p, https://www.ohmprovence.org/IMG/pdf/tohm-01_20115484.pdf.

Morgan A.C., Economou D.J., Way S.F. and Clauset A., 2018, Prestige drives epistemic inequality in the diffusion of scientific ideas, EPJ Data Science volume 7, Article number: 40.

Ogien, A (2015) 'Doubt, Ignorance and Trust: On the unwarranted fears raised by the doubt-mongers' pursuit', in: Gross M., McGoey, L (eds) Routledge International Handbook of Ignorance Studies, ch. 20, Routledge, Londres, pp 192-198.

Proctor, R.N. and Schiebinger L. (eds) (2008) Agnotology: The Making and Unmaking of Ignorance, Standford University Press.

Séralini, G-E., Claire, E., Mesnage, R., Gress, S., Defarge, N., Malatesta, M., Hennequin, D. and Spiroux de Vendômois, J. (2012) 'RETRACTED: Long term toxicity of a Roundup herbicide and a Roundup-tolerant genetically modified maize' Food and Chemical Toxicology, vol. 50, No 11, pp 4221-4231.

Steinpreis, R.E., Anders, K.A. and Ritzke, D. (1999) 'The Impact of Gender on the Review of the Curricula Vitae of Job Applicants and Tenure Candidates: A National Empirical Study', Sex Roles, Vol 41 No 7-8, pp 509-528.

Stengers, I (2001) La guerre des sciences aura-t-elle lieu ? Les Empêcheurs de penser en rond, Paris.

Tsoukias, A.,

Tsuda, T., Yorifuji, T., Takao, S., Miyai, M. and Babazono A. (2009) 'Minamata disease: Catastrophic poisoning due to a failed public health response', Journal of Public Health Policy, Vol. 30, No 1, pp 54-67.

Vermeylen S, 2019, Special issue: environmental justice and epistemic violence, Local Environment, 24:2, 89-93, DOI: $\underline{10.1080 / 13549839.2018 .1561658}$

Williams K.D., 2007, Ostracism, Annual Review of Psychology, Vol. 58:425-452. https://doi.org/10.1146/annurev.psych.58.110405.085641

Zonabend, F. (2014) La presqu'île au nucléaire, Odile Jacob, Paris. 